\title{
PENGARUH DISTRAKSI DAN KUALITAS TIDUR TERHADAP TINGKAT KEWASPADAAN PENGEMUDI BRT KORIDOR I (MANGKANG - PENGGARON)
}

\author{
Wiwik Budiawan*, Sriyanto, Inggriet Hermanda \\ Program Studi Teknik Industri, Fakultas Teknik, Universitas Diponegoro \\ Jl. Prof. Soedharto, SH, Kampus Undip Tembalang, Semarang, Indonesia 50275
}

(Received: January 24, 2017 / Accepted: February 28. 2017)

\begin{abstract}
Abstrak
Kecelakaan merupakan masalah yang belum terselesaikan di jalan raya. Hal ini dibuktikan dengan semakin banyaknya jumlah korban kecelakaan yang ada dijalan raya, walaupun jumlah kecelakaannya yang terjadi setiap tahunnya menurun namun jumlah korbannya berbanding terbalik dengan jumlah kecelakaan yang terjadi. Salah satu yang menyebabkan hal ini terjadi adalah angkutan - angkutan yang dapat mengangkut banyak orang, salah satunya Bus Rapid Transit (BRT). Faktor yang sangat berpengaruh terhadap kecelakaan yang tinggi adalah Driver error, dimana tingkat kewaspadaan yang rendah menyebabkan pengemudi tidak fokus mengemudi. Tingkat kewaspadaan dapat diukur menggunakan software Psychomotor Vigilance Test (PVT) Hal yang dapat mengurangi tingkat kewaspadaan adalah kualitas tidur yang rendah yang dapat diukur menggunakan kuisioner Pittsburgh Sleep Quaity Index (PSQI). Selain kualitas tidur faktor lain yang mempengaruhi tingkat kewaspadaan adalah distraksi, yang dapat diukur menggunakan kuisioner Susceptibility to Driver Distraction Questinnaire (SDDQ). Kedua faktor ini akan dihubungkan dengan tingkat kewaspadaan menggunakan regresi linier majemuk. Hasil penelitian menunjukkan bahwa tingkat kewaspadaan dipengaruhi oleh kualitas tidur sebelum pengemudi bekerja, sedangkan sesudah bekerja tingkat kewaspadaan dipengaruhi distraksi.
\end{abstract}

Kata kunci : kualitas tidur; PSQI distraksi; SDDQ; PVT; tingkat kewaspadaan

\begin{abstract}
Accident is a problem that not finish yet at the road. This fact can be evidence by the increasing of number victim's accident at the road. Although number of accidents are decrease every years but the number of victims are increased. One type of vehicle in the road is public transportation that can accommodate many people. That's way public transportation can make many victims if an accident. One type of public transportation in Semarang is Bus Rapid Transit (BRT). Driver error is a factor for increased number of accident, vigilance extent for driver error has an influence with accident in the road. If the driver has a low level of vigilance can make driver not focused on driving. Level of vigilance can be measured by software Psychomotor Vigilance Test (PVT). Factors that can make vigilance level for driver decreased are quality of sleep and distraction. Quality of sleep can measured by Pittsburgh Sleep Quality Index (PSQI) questionnaire. Then Distraction for driver can be measured by Susceptibility to Driver Distraction Questionnaire $(S D D Q)$. Both of these factors will be linked to the level of vigilance using linear regression. The results showed that the level of inattention is affected by the quality of the driver's sleep before work, after work while the level of vigilance is affected distraction.
\end{abstract}

${ }^{*}$ Penulis Korespondensi.

Email : Wiwikbudiawan@gmail.com

J@TI UNDIP : JURNAL TEKNIK INDUSTRI, Vol. XII, No. 1, Januari 2017 
Keywords : sleep quality; PSQI; distraction; SDDQ; PVT; inatenntiom

\section{Pendahuluan}

Kecelakaan lalu lintas merupakan masalah yang sering terjadi di jalan raya. Masalah ini dianggap serius karena tidak sedikit yang kehilangan nyawa karena kecelakaan lalu lintas. Laporan Satuan lalu lintas (Satlantas) Kota Semarang menunjukkan bahwa jumlah korban meninggal dunia akibat kecelakaan dari tahun 2013 hingga 2015 mengalami peningkatan. Dari 196 orang korban jiwa di tahun 2013 dari 957 kecelakaan yang terjadi. Data terakhir menunjukkan bahwa terdapat 238 korban jiwa dari 872 pada tahun 2015.

Salah satu kendaraan yang menampung banyak muatan dan setiap hari beroperasi di Kota Semarang adalah Bus Rapid Transit (BRT). Di Kota Semarang terdapat empat Koridor BRT, koridor yang paling ramai dan sering digunakan adalah koridor I, selain itu, bus yang digunakan koridor I berukuran lebih besar jika dibandingkan dengan tiga koridor lainnya. Jumlah kecelakaan yang terjadi pada BRT koridor I dari tahun ke tahun meningkat, hal ini dibuktikan dengan adanya data dari pihak BRT, dimana pada tahun 2013 terdapat 11 kejadian kecelakaan dan pada tahun 2015 terjadi 15 kejadian kecelakaan (Imam, 2016)

Pengemudi BRT yang melakukan pekerjaannya kurang lebih selama 12 jam. Hal ini membuat jam tidur mereka menjadi sekitar 4 - 6 jam dalam sehari (Imam, 2016). Tingkat kewaspadaan saat erat dengan kelelahan yang dirasakan oleh pengemudi, karena semakin tinggi tingkat kelelahan maka akan semakin tinggi pula tingkat kewaspadaan (Tama \& Oktavianty, 2014). Dalam penelitian yang dilakukan oleh National Highway Traffic Safety Administration (NHTSA), mengatakan bahwa salah satu yang menyebabkan berkurangnya tingkat kesiapan "Attentive driver" disebabkan karena pengemudi megalami "drowsiness" yaitu kantuk yang tinggi mempengaruhi secara signifikan terhadap tingkat kewaspadaan pengemudi dan menyebabkan "Driver Inattention" . (Klauer, Dingus, Neale, Sudweeks J.D, \& Ramsey, 2006).

Distraksi pada pengemudi adalah segala sesuatu yang mempengaruhi perhatian pengemudi saat dijalan atau gangguan visual, audio, pikiran dan gangguan kognitif lainnya (Dingus, et al., 2006). Distraksi mempengaruhi kewaspadaan pengemudi dalam melakukan pekerjaannya, dimana distraksi akan mempengaruhi driving performance dan mempengaruhi kewasapadaan pengemudi (Qun, 2009). Dari penjelasan tersebut dapat ditinjau lebih dalam faktor yang dapat membuat menurunnya tingkat kewaspadaan dan mengakibatkan kecelakaan lalu lintas.

\section{Metode Penelitian \\ 1. Desain Penelitian}

Objek penelitian adalah Bus Rapid Transit (BRT) koridor I Semarang. Data diperoleh melalui kuisioner dan simulasi software tingkat kewaspadaan kepada pengemudi BRT koridor I. Kuisioner yang dibagikan terdiri dari dua jenis kuisioner yaitu kuisioner Pittsburgh Sleep Quaity Index (PSQI) (Buysse, et al., 1988) yang digunakan untuk mengukur kualitas tidur dan kuisioner Susceptibility to Driver Distraction Questinnaire (SDDQ) (Feng, Marulands, \& Donmez, 2014) yang digunakan khusus untuk mengukur distraksi pengemudi. Pengukuran tingkat kewaspadaan digunakan dengan menggunakan software PVT, untuk melihat Average Reaction Time.

PSQI terdiri dari 9 pertanyaan yang diberi nilai dan dijawab oleh individu responden itu sendiri. Penentuan kualitas tidur yang baik atau buruk dilakukan dengan mengukur tujuh area tadi. Berikut adalah cara menghitung hasil kuisioner PSQI:

- Komponen 1: mengacu pada nomor 9 (dengan nilai: $0,1,2,3)$

- Komponen 2: mengacu pada nomor $2(\leq 15$ menit $=$ $0 ; 16-30$ menit $=1 ; 31-60$ menit $=2 ;>60$ menit $=3)+$ nilai pada nomor $5 \mathrm{a}(0,1,2,3,4)$

- Komponen 3: mengacu pada nomor 4 ( $>7 \mathrm{jam}=0$; $6-7 \mathrm{jam}=1 ; 5-6=2 ;<5 \mathrm{jam}=3$ )

- Komponen 4: mengacu pada nomor 1, 3, dan 4. (total jam tidur/ total jam di Kasur x 100\%) dimana $(>85 \%=0 ; 75 \%-84 \%=1 ; 65 \%-74 \%=2 ;$ dan $<65 \%=3$ )

- Komponen 5: Penjumlahan dari nilai 5b sampai 5j (0 $=0,1-9=1.10-18=2,19-27=3$ )

- Komponen 6: mengacu pada nomor $6(0,1,2,3,4)$

- Komponen 7: mengacu pada nomor 7 dan 8 dimana score pertanyaan nomor $7+$ score pertanyaan nomor $8 .(0=0,1-2=1,3-4=2,5-6=3,7-8$ $=4)$.

Validitas penelitian PSQI sudah teruji, instrumen ini menghasilkan 7 skor yang sesuai dengan domain atau area yang disebutkan diatas. Tiap domain nilainya berkisar antara 0 (tidak ada masalah) sampai 4 (masalah berat). Nilai tiap komponen kemudian dijumlahkan menjadi skor global antara $0-25$. Skor global > 5 dianggap memiliki gangguan tidur yang signifikan (Maurits, 2008). 
Indikator dalam mengukur gangguan adalah menggunakan Susceptibility to Driver Distraction Questionnare (SDDQ). Dimana kuisioner ini dikhusukan untuk pengemudi. Terdapat tiga bagian dalam SDDQ:

1. Distraction Engagement

2. Attitude and Beliefs about voluntary distraction

3. Susceptibility to Involuntary Distraction

Dalam bagian tersebut terdapat beberapa pertanyaan yang mengacu pada hal - hal yang menyebabkan distraksi pengemudi. Bagian distraction Engagement merupakan bagian yang merangkum tentang hal - hal apa saja yang membuat terganggunya pengemudi. Bagian kedua yang kedua yaitu sikap pengemudi jika terdapat gangguan yang bersifat disengaja misalnya pengemudi sengaja membalas pesan singkat lewat telepon genggam atau membaca iklan iklan yang terdapat di pinggir jalan. Bagian ketiga adalah kerentanan pengemudi ketika didapatkan gangguan yang tidak disengaja dibuat seperti adanya iklan di pinggir jalan, tidak sengaja mendengarkan musik di radio kendaraan (Feng, Marulands, \& Donmez, 2014)

PVT menjadi alat yang cocok untuk digunakan untuk mengukur performansi pekerja dilapangan karena kemudahan menggunakannya dan mudah dipindahkan dari suatu tempat ke tempat lain (Basner, Mollicone, \& Dinges, 2011). PVT yang sering digunakan dalam pengukuran adalah PVT dengan durasi 10 menit. Dalam durasi 10 menit, PVT akan memunculkan angka dengan selang waktu random (bisa lebih cepat atau lambat), angka tersebut diasumsikan sebagai sebuah stimulus yang diberikan kepada responden. Ketika angka itu muncul, responden harus menekan tombol klik kanan mouse untuk merespon stimulus tersebut. Lamanya responden itulah yang akan menjadi output dari hasil pengukuran kelelahan menggunakan PVT. Karena, apabila responden mengalami kelelahan atau beberapa sikap seperti kantuk atau stress, maka kecepatan respon pun akan menurun. Pengambilan data yang dilakukan menggunakan PVT ini yaitu pada saat sebelum pengemudi bekerja dan sesudah pengemudi bekerja.

\section{Pengembangan Hipotesis dan Model Penelitian}

Berdasarkan penelitian sebelumnya, penelitian mengenai distraksi dan kualitas tidur hanya dilakukan pada pengemudi mobil pribadi, pada penelitian tersebut pengukuran distraksi dan tingkat kantuk (drowsiness) menggunakan perhitungan jumlah kedip mata (Siswanto, Loice, \& Chandra, 2014). Hal ini memakan waktu yang cukup lama untuk melihat berapa kedipan mata pengemudi dan tidak efektif. Perbedaan objek penelitian yang digunakan menjadi salah satu hal yang mendukung dilakukannya penelitian tersebut dikarenakan bahwa pegemudi BRT memiliki tanggung jawab yang lebih besar dibandingkan pengemudi mobil pribadi. Sehingga, posisi penelitian yang akan dilakukan adalah meneliti pengaruh kualitas tidur dan distraksi terhadap tingkat kewaspadaan pengemudi BRT koridor I jurusan Mangkang - Penggaron.

Jumlah kecelakaan yang tinggi disebabkan oleh pengemudi yang dikarenakan ketidakwaspadaan, dimana ketidakwaspadaan ini dibubungkan dengan kurangnya waktu tidur dari pengemudi tersebut (Strayer, et al., 2013). Dalam penelitian ini bahkan pengemudi mendapatkan sleep apnea, hal ini merupakan lemasnya otot tenggorokan saat tidur yang membuat tenggorokan menyempit dan tidak bisa bernafas secara normal.

Tingkat kantuk dan Distraksi mempengaruhi tingkat kewaspadaan pengemudi secara serius (Desai \& Haque, 2006). Penelitian ini dilakukan untuk memperhatikan kapan pengemudi itu mulai tidak waspada, dimana data ini nantinya akan digunakan oleh organisasi di Eropa yang bergerak di bidang Safety Transportation. Hal ini bertujuan untuk memberikan evaluasi dan merenacang perbaikan dan solusi agar tidak berkurangnya tingkat kewaspadaan pengemudi.

Penelitan yang bergerak dibidang Human Error in Road Accidents yang membahas tentang kecelakaan lalu linta paling banyak disebabkan oleh pengemudi yang tidak waspada (Green \& Senders, 2013). Penelitian ini merupakan penelitian terbaru yang dilakukan mengenai kecelakaan angkutan yang disebabkan oleh ketidak waspadaan pengemudi. Selanjutnya penelitian ini akan mengacu kepada penelitian - penelitian yang sudah disebutkan diatas. Dari penelitian - penelitian diatas, didapatkan lah model penelitian pada gambar 1

Penelitian yang dilakukan ini juga membahas tentang tingkat kewaspadaan pengemudi, dimana objek yang diambil adalah pengemudi BRT koridor I. dari gambar 1 dapat diambil beberapa hipotesis yang dapat didapatkan, dimana terdapat tiga variabel dalam penelitian ini, yaitu dua variabel dependen yang terdiri dari distraksi dan kualitas tidur, kemudian variabel independennya adalah tingkat kewaspadaan. Dari variabel - variabel yang ada dapat diambil beberapa hipotesis yaitu:

- Hipotesis 1 : Kualitas Tidur dan Distraksi Berpengaruh Secara Simultan Terhadap Tingkat Kewaspadaan

- Hipotesis 2 : Kualitas Tidur dan Distraksi Berpengaruh Secara Partial Terhadap Tingkat Kewaspadaan.

- Hipotesis 3 : Kualitas Tidur Berpengaruh signifikan secara individual terhadap Tingkat Kewaspadaan.

- Hipotesis 4 : Distraksi Berpengaruh signifikan secara individual terhadap Tingkat Kewaspadaan. 


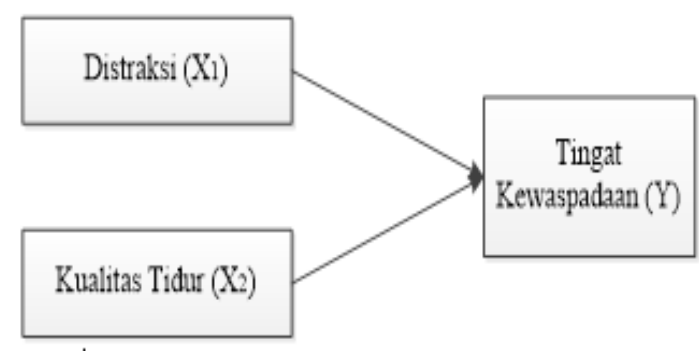

Gambar 1. Metode Konseptual Penelitian

\section{Hasil dan Pembahasan \\ 1. Pengolahan Data}

Data didapatkan dari score kuisioner PSQI dan SDDQ, kemudian nilai average reaction time yang didapatkan dari output PVT. Responden yang mengisi kuisioner dan yang melakukan simulasi software PVT adalah pengemudi BRT koridor I Semarang dengan jumlah 30 orang, dimana rute dari BRT koridor I ini adalah Mangkang - Penggaron. Jadi proses pengambilan data juga dilakukan di dua tempat, yaitu Mangkang dan Penggaron.

Metode yang digunakan untuk mengetahui pengaruh kualitas tidur dan distraksi terhadap tingkat kewaspadaan pengemudi BRT adalah regresi linier majemuk, dimana variabel dependennya adalah tingkat kewaspadaan dan variabel independennya adalah kualitas tidur dan distraksi.

Sebelum dilakukannya regresi linier majemuk tersebut terdapat beberapa uji asumsi klasik yang harus dipenuhi yaitu:
- Uji Normalitas

Uji Normalitas bertujuan untuk mengetahui distribusi data dalam variabel yang digunakan dalam penelitian. Data yang baik dan layak yang digunakan dalam penelitian adalah data yang berdistribusi normal. Untuk menguji apakah distribusi normal atau tidak dapat dilihat menggunakan uji statistik non - parametrik Kolmogorov - Smirnov (KS). Jika hasil Kolmogorov - Smirnov (KS) menunjukkan nilai signifikan > 0,05 maka data residual terdistribusi dengan normal (Arifiyani, 2012)

- Uji Linieritas

Uji ini digunakan untuk melihat apakah spesifikasi model yang digunakan sudah benar atau tidak. Pengujian linearitas antara variabel dependen dan variabel independen dapat dilakukan dengan melihat nilai $\mathrm{p}$ value (deviation from linearity $>0,05$, apabila syarat tersebut terpenuhi maka dapat dikatakan bahwa model regresi linear (Arifiyani, 2012).

- Uji Heterokedastisitas

Uji heteroskesdesitas bertujuan untuk menguji apakah dalam model regresi terjadi perbedaan variance residual suatu periode pengamatan ke periode pengamatan yang lain. Jika variance residual suatu pengamatan ke pengamatan yang lain tetap, maka disebut homoskesdesitas dan jika berbeda disebut heteroskesdesitas. Model regresi yang baik adalah model regresi yang memiliki kesamaan variance residual suatu periode pengamatan dengan pengamatan yang lain, atau homoskesdesitas dan tidak terjadi heterokesdesitas.

Tabel 1. Rekapitulasi Hasil Pengolahan Data Untuk Keadaan Sebelum Bekerja

\begin{tabular}{|c|c|c|c|c|}
\hline \multirow[b]{2}{*}{ No } & \multirow[b]{2}{*}{ Kriteria } & \multicolumn{3}{|c|}{ Sebelum Bekerja } \\
\hline & & Kualitas Tidur & Distraksi & $\begin{array}{l}\text { Tingkat } \\
\text { Kewaspadaan }\end{array}$ \\
\hline 1 & Uji Multikolinieritas & \multicolumn{3}{|c|}{ Lolos Uji } \\
\hline 2 & Uji Heteroskesdastisitas & \multicolumn{3}{|c|}{ Lolos Uji } \\
\hline 3 & Uji Normalitas & \multicolumn{3}{|c|}{ Lolos Uji } \\
\hline 4 & Uji Linieritas & \multicolumn{3}{|c|}{ Lolos Uji } \\
\hline 5 & Uji F & \multicolumn{3}{|c|}{$\begin{array}{c}\text { Hipotesis } 1 \text { berpengaruh secara bersama - sama/ simultan ( } \mathrm{p} \text {-value } \\
>0.05 \text { dan } \mathrm{F} \text { hitung }<\mathrm{F} \text { tabel) }\end{array}$} \\
\hline 6 & Uji t & \multirow[t]{2}{*}{$\begin{array}{c}\text { Hipotesis } 2 \\
\text { berpengaruh } \\
\text { secara partial }\end{array}$} & \multicolumn{2}{|c|}{$\begin{array}{c}\text { Hipotesis } 3 \\
\text { berpengaruh secara } \\
\text { partial }\end{array}$} \\
\hline 7 & Adjusted R Square & & \multicolumn{2}{|c|}{0.04} \\
\hline 8 & $\begin{array}{l}\text { Variabel yang paling } \\
\text { Berpengaruh }\end{array}$ & \multicolumn{3}{|c|}{ Kualitas Tidur } \\
\hline
\end{tabular}


Tabel 2. Rekapitulasi Hasil Pengolahan Data Untuk Keadaan Sesudah Bekerja

\begin{tabular}{|c|c|c|c|c|}
\hline \multirow[b]{2}{*}{ No } & \multirow[b]{2}{*}{ Kriteria } & \multicolumn{3}{|c|}{ Sesudah Bekerja } \\
\hline & & Kualitas Tidur & Distraksi & $\begin{array}{c}\text { Tingkat } \\
\text { Kewaspadaan }\end{array}$ \\
\hline 1 & Uji Multikolinieritas & \multicolumn{3}{|c|}{ Lolos Uji } \\
\hline 2 & Uji Heteroskesdastisitas & \multicolumn{3}{|c|}{ Lolos Uji } \\
\hline 3 & Uji Normalitas & \multicolumn{3}{|c|}{ Lolos Uji } \\
\hline 4 & Uji Linieritas & \multicolumn{3}{|c|}{ Lolos Uji } \\
\hline 5 & Uji F & \multicolumn{3}{|c|}{$\begin{array}{c}\text { Hipotesis } 1 \text { berpengaruh secara bersama - sama/ simultan }(\mathrm{p}- \\
\text { value }>0.05 \text { dan } \mathrm{F} \text { hitung }<\mathrm{F} \text { tabel })\end{array}$} \\
\hline 6 & Uji t & \multirow[t]{2}{*}{$\begin{array}{c}\text { Hipotesis } 2 \\
\text { berpengaruh } \\
\text { secara partial }\end{array}$} & \multicolumn{2}{|c|}{$\begin{array}{l}\text { Hipotesis } 3 \\
\text { berpengaruh secara } \\
\text { partial }\end{array}$} \\
\hline 7 & Adjusted R Square & & \multicolumn{2}{|c|}{0.062} \\
\hline 8 & $\begin{array}{l}\text { Variabel yang paling } \\
\text { Berpengaruh }\end{array}$ & \multicolumn{3}{|c|}{ Distraksi } \\
\hline
\end{tabular}

- Uji Multikolinearitas

Uji multikolinearitas, diperlukan untuk mengetahui apakah ada tidaknya variabel independen yang memiliki kemiripan dengan variabel independen lain dalam satu model. Deteksi multikolinearitas pada suatu model dapat dilihat jika nilai Variance Inflation Factor (VIF) tidak lebih dari 10 dan nilai Tolerance tidak kurang dari 0,1 maka model tersebut dapat dikatakan terbebas dari multikolinearitas. VIF $=1 /$ Tolerance, jika VIF $=10$ maka Tolerance $=1 / 10=0,1$. Nilai VIF merupakan tingkat keeratan hubungan antara suatu variabel bebas dengan variabel bebas lainnya (Arifiyani, 2012).

Setelah semua uji asumsi klasik sudah lolos uji baru dilakukan regresi linier majemuk yang dilakukan dengan menggunakan software SPSS. Nilai tingkat kewaspadaan terdapat pada dua keadaan yaitu sebelum pengemudi bekerja dan sesudah pengemudi bekerja. Maka dari itu, juga dihasilkan dua persamaan regresi dari output SPSS, dimana persamaan 1 merupakan output regresi sebelum pengemudi bekerja dan persamaan 2 merupakan output regresi sesudah pengemudi bekerja :

$$
\mathrm{Y}=1.025+0.020 \mathrm{x}_{1}+0.005 \mathrm{x}_{2}
$$

Dari persamaan 1 didapatlah bahwa tingkat kewaspadaan sebelum jam mengemudi memiliki nilai konstanta 1.025 dan unstandardized beta coefficients dari uji regresi variabel kualitas tidur sebesar 0.020 dan distraksi sebesar 0.005 .

$$
\mathrm{Y}=1.752-0.013 \mathrm{x}_{1}+0.064 \mathrm{x}_{2} \ldots \ldots \ldots \ldots \ldots \text { (2) }
$$

Dari persamaan 2 didapatlah bahwa tingkat kewaspadaan sesudah jam mengemudi memiliki nilai konstanta sebesar 1.752 dan unstandardized beta coefficients dari uji regresi variabel kualitas tidur sebesar -0.013 dan distraksi sebesar 0.064 .

Setelah didapatkan persamaan regresinya kemudian dilanjutkan dengan menguji keempat hipotesis dengan menggunakan uji $\mathrm{F}$, uji $\mathrm{t}$ dan nilai koefisien determinasi $\left(\mathrm{R}^{2}\right)$ sehingga didapatlah hasil secara untuk pengaruh tingkat kewaspadaan sebelum bekerja pada tabel 1 dan sesudah kerja pada tabel 2. Dari tabel 1 didapatkanlah hasil bahwa diantara distraksi dan kualitas tidur yang paling mempengaruhi tingkat kewaspadaan pengemudi sebelum melakukan pekerjaan adalah kualitas tidur. Sedangkan pada tabel 2 memperlihatkan bahwa yang paling mempengaruhi tingkat kewaspadaan sesudah bekerja adalah distraksi.

\section{Kesimpulan}

Penelitian ini bertujuan untuk mengetahui mana apa yang paling mempengaruhi tingkat kewaspadaan pengemudi BRT koridor I Semarang antara faktor kualitas tidur dan distraksi, ternyata keduanya mempengaruhi, namun dalam waktu yang berbeda, dimana saat sebelum memulai pekerjaan tingkat kewaspadaan dipengaruhi oleh kualitas tidur, sedangkan sesudah bekerja tingkat kewaspadaan dipengaruhi oleh distraksi.

Rekomendasi yang tepat untuk meningkatkan tingkat kewaspadaan pengemudi BRT koridor I adalah mengatur kembali jam kerja pengemudi sesuai peraturan yang mengatakan maksimal mengemudi yaitu selama 8 jam dalam sehari. Sedangkan pelaksanaan pengemudi BRT sekarang \pm 12 jam perhari. 
Solusinya bisa dilakukan dengan menerapkan sistem shift kerja. Jika pengemudi masuk pukul 06.00 hingga 18.00. jam kerja tersebut bisa dibagi menjadi 2 bagian yaitu mulai pukul 06.00 hingga 12.00 dan mulai pukul 12.00 hingga 18.00. hal seperti ini lebih efektif karena, pengemudi hanya melakukan pekerjaannya selama 6 jam dalam sehari.

Solusi yang bisa dilakukan untuk distraksi diantaranya yaitu dengan melaporkan kepada pemerintah mengenai iklan yang menggunakan cahaya seperti televisi yang ada dijalan untuk lebih dikontrol cahayanya, karena hal tersebut dapat mengganggu pandangan pengemudi yang mengendarai kendaraan kendaraan besar seperti bus dan truk yang posisinya hamper sejajar dengan iklan tersebut.

\section{Daftar Pustaka}

Arifiyani, H. A. (2012). Pengaruh Pengendalian Intern, Kepatuhan dan Kompensasi Manajemen Terhadap Perilaku Etis Karyawan. Universitas Negeri Yogyakarta, 1(1), 6-12.

Basner, M., Mollicone, D., \& Dinges, D. F. (2011). Validity and Sensitivy of a brief psychomotor Vigilance test to Total and Partial Sleep Deprivation. Elsevier, 69, 949-959.

Buysse, D. J., F, C., III, R., Monk, T. H., Berman, S. R., \& Kupfer, D. J. (1988). The Pittsburgh Sleep Quality Index : A New Instrument for Psychiartric Practice and Research. Psychiatry, 28, 193-213.

Desai, A., \& Haque, M. (2006). Vigilance Monitoring for Operator Safety: A Simulation Study On Highway Driving. Safety Research, 37, 139-147.
Dingus, T., Kaluer, S., Neale, V., Petersen , A., Lee, S., E, S., . . Knipling, R. (2006). The 100-Car Naturalistic Driving Study. Washingtong DC: NHTSA.

Feng, J., Marulands, S., \& Donmez, B. (2014). Susceptibility to Driver Distraction Questionnaire. Transportation Research, 1, 25-34.

Green, M., \& Senders, J. (2013). Human Error in Road Accidents. Canada: Visual Expert.

Imam (2016). Bus Rapid Transit. BLU.

Klauer, S., Dingus, T., Neale, V., Sudweeks J.D, \& Ramsey, D. (2006). The Impact of Driver Inattention on Near-Crash/Crash Risk. Washington, DC: NHTSA.

Maurits, L. S. (2008). Faktor dan Penjadualan Shift Kerja. Teknoin, 13(2), 11-22.

Qun, W. (2009). An Overview of driving Distraction Measure Methods. College of Computer Science and Engineering, 2(2), 2391-2394.

Siswanto, D., Loice, R., \& Chandra, K. (2014). Perancangan Alat Deteksi Kantuk dan Analisis Tingkat Kantuk Pengemudi Bus Malam X. Universitas Parahyangan, 1(1), 51-56.

Strayer, D. L., Cooper, J. M., Turrill, J., Coleman, J., Medeirosward, N., \& Biondi, F. (2013). Measuring Cognitive Distraction in the Automobile. Washington DC: AAAFoundation.

Tama, I. P., \& Oktavianty, O. (2014). Evaluasi Pengaruh Pola Kerja Terhadap Fatique Untuk Mengurangi Jumlah Kecelakaan. Jurnal Teknik Industri, 2(2), 3741. 